https://edukatif.org/index.php/edukatif/index

\title{
PENGARUH PENGGUNAAN MUSIK TERHADAP KONSENTRASI BELAJAR ANAK SEKOLAH DASAR
}

\author{
Cahyo Dwi Andita ${ }^{1}$, Desyandri ${ }^{2}$ \\ Universitas Negeri Padang, Sumatera Barat, Indonesia ${ }^{1,2}$ \\ e-mail : cahyodwiandita23101996@gmail.com ${ }^{1}, \underline{\text { desyandri@ fip.unp.ac.id }}^{2}$
}

\begin{abstract}
Abstrak
Musik merupakan segala sesuatu yang menyenangkan, mendatangkan keceriaan, mempunyai irama (ritme), melody, timbre (tone colour) tertentu untuk membantu tubuh dan pikiran saling bekerja sama. Musik telah lama dianggap memiliki pengaruh terhadap tubuh maupun jiwa manusia. Mendengarkan musikmusik ketika melaksanakan pembelajaran disamping menciptakan kenyamanan dalam belajar juga dapat meningkatkan konsentrasi anak dalam belajar. Beberpa musik-musik populer (misalnya Baroque String Conceert) sangat efektif untuk membaca dan meningkatkan konsentrasi, sedangkan musik klasik dan Baroque, apabila dirancang secara khusus dapat meningkatkan konsentrasi dan keinginan belajar.
\end{abstract}

Kata Kunci: Musik, Konsentrasi, Anak SD

\begin{abstract}
Music is everything that is fun, brings joy, has a rhythm (rhythm), melody, timbre (tone color) to help the body and mind work together. Music has long been considered to have an influence on the human body and soul. Listening to music when carrying out learning while creating comfort in learning can also increase children's concentration in learning. Some popular music (for example Baroque String Conceert) is very effective for reading and increasing concentration, while Classical and Baroque music, if specifically designed can increase concentration and desire to learn.
\end{abstract}

Keywords: Music, Consentration, Elementary School Children

$\triangle$ Corresponding author :

Address :

Email :

Phone
ISSN 2656-8063 (Media Cetak)

ISSN 2656-8071 (Media Online) 


\section{PENDAHULUAN}

Memasuki usia Sekolah Dasar (SD) anak berada pada usia 6-12 tahun, menurut teori perkembangan kognitif Piaget anak usia sekolah sudah memasuki tahap berpikir konkret dimana pada usia ini anak sudah dapat berpikir secara logis dan masuk akal tentang suatu hal. Anak juga sudah dapat mengklasifikasikan, mengurutkan, menyusun serta mengatur strategi dalam menyelesaikan masalah. Tugas utama anak usia sekolah adalah belajar. Keberhasilan dalam belajar dipengaruhi oleh banyak faktor salah satunya yaitu konsentrasi. Anak usia sekolah dapat berkonsentrasi pada lebih dari satu aspek situasi serta mereka dapat memahami suatu objek dari sudut pandang yang berbeda. Di lingkungan sekolah, anak harus berkecimpung dengan berbagai tujuan dan agenda pembelajaran. Dengan memaksakan otak untuk bekerja sangat keras, akan terjadi ketidakseimbangan antara otak kanan dan otak kiri, sehingga menyebabkan kelelahan pada otak yang berakibat pada penurunan konsentrasi belajar anak di sekolah, Nuryana \& Purwanto (dalam Apriyani, Parjo, \& Rahmadhaniyati, 2015)

Konsentrasi adalah memusatkan segenap kekuatan perhatian pada suatu situasi belajar. Konsentrasi juga dapat diartikan sebagai usaha seseorang untuk memfokuskan perhatian pada suatu objek sehingga dapat memahami dan mengerti objek yang diperhatikan. Proses pembelajaran membutuhkan konsentrasi, oleh karena itu setiap anak dalam mengikuti pembelajaran di sekolah diharapkan dapat berkonsentrasi dengan baik. Kemampuan anak dalam berkonsentrasi akan mempengaruhi kecepatan dalam menangkap materi yang diberikan oleh guru pada proses pembelajaran. Oleh karena itu diperlukan suatu metode yang menyenangkan yang membuat anak rileks dalam belajar dan dapat memusatkan konsentrasinya pada pembelajaran yang sedang berlangsung (Apriyani et al., 2015).

Salah satu metode yang dapat digunakan untuk membuat anak rileks dalam belajar adalah dengan terapi musik. Musik merupakan segala sesuatu yang menyenangkan, mendatangkan keceriaan, mempunyai irama (ritme), melody, timbre (tone colour) tertentu untuk membantu tubuh dan pikiran saling bekerja sama. Musik telah lama dianggap memiliki pengaruh terhadap tubuh maupun jiwa manusia. Musik adalah salah satu media ungkapan kesenian, musik juga diartikan sebagai ilmu atau seni menyusun nada atau suara diutarakan, kombinasi dan hubungan temporal untuk menghasilkan komposisi suara yang mempunyai keseimbangan dan kesatuan, nada atau suara yang disusun sedemikian rupa sehingga mengandung irama, lagu dan keharmonisan terutama yang dapat menghasilkan bunyi-bunyi itu(Izam, 2016)

Demikian pula telah berkembang anggapan dalam masyarakat bahwa musik klasik paling membantu dalam perkembangan intelektulitas. Apabila jenis musik tertentu benar-benar dapat membantu aktivitas otak maka hal ini dapat menolong prestasi belajar siswa. Salah satu jenis musik yang sering digunakan dalam pengkondisian situasi belajar atau situasi kerja adalah jenis musik klasik. Musik klasik memiliki irama lambat dan dapat ditemukan dalam semua genre musik yang dapat memberikan perasaan tenang dan perasaan damai adalah musik dengan irama yang lebih lambat (Wulansari, Dewi, \& Murni, 2019)

Oleh karena itu penulis tertarik menulis artikel tentang pengaruh penggunaan musik terhadap daya tahan konsetrasi belajar anak SD.

\section{METODE PENELITIAN}

Metode yang digunakan dalam penulisan artikel ini adalah Studi literature/Literature review yang membahas tentang pengaruh penggunaan musik terhadap daya tahan konsentrasi belajar anak SD. Studi literatur yang dilakukan oleh penulis yaitu dengan membaca dan mengevaluasi penelitian-penelitian sebelumnya, serta melakukan pencarian terhadap berbagai sumber tertulis, baik berupa buku-buku, artikel, dan jurnal, atau dokumen-dokumen yang relevan dengan permasalahan yang dikaji. Sehingga informasi yang didapat dari studi kepustakaan ini dijadikan rujukan untuk memperkuat argumentasi-argumentasi yang ada dalam tulisan ini.

\section{HASIL DAN PEMBAHASAN PENELITIAN}

Salah seorang ilmuwan dari timur tengah, Al-Farabi Di dalam bukunya, Great Book About Music, Al-Farabi mengatakan bahwa musik dapat membuat rasa tenang atau nyaman, sebagai pendidikan moral, mengendalikan emosi, pengembangan spiritual, dan menyembuhkan gangguan psikosomatik. Musik yang dapat memberikan ketenangan dan kedamaian adalah musik dengan tempo yang lebih lambat. Musik dengan tempo lambat tersebut dapat ditemukan dalam semua genre, salah satunya adalah musik instrumen. Hal ini dapat memberikan gambaran adanya hubungan antara musik dengan respon 
seseorang yang sebenarnya tidak jauh dari hubungan emosi antar musik dan pendengar. Oleh karena itu, pendengar dapat merasakan ketenangan maupun kedamaian dengan mendengarkan musik secara tiba-tiba.

Senada dengan pendapat di atas, menurut Supradewi (2010) mengungkapkan bahwa musik berpengaruh kuat pada lingkungan belajar. Penelitian menunjukkan bahwa belajar lebih mudah dan cepat jika pelajar dalam kondisi santai dan reseptif. Detak jantung orang dalam keadaan ini adalah 60 sampai 80 kali per menit. Kebanyakan musik barok sesuai dengan kondisi detak jantung manusia yang santai dalam kondisi belajar optimal. Dalam keadaan ini otak memasuki gelombang alfa (8-12 Hz), gelombang otak yang terjadi pada saat seseorang mengalami relaksasi (Pasiak, 2007; Mustajib, 2010). Gelombang alfa merupakan "kewaspadaan yang rileks" (relaxed alertness) atau kadang juga disebut "kesadaran yang rileks" (relaxed awareness). Otak pada ritme alfa adalah kondisi otak yang rileks namun waspada, sehingga bagian dari otak, yaitu hippocampus dan somatosensory, dapat bekerja dengan optimal, Ostrander \& Schoeder ( dalam Supradewi, 2010)

Musik dapat mempengaruhi perkembangan otak karena sifat plantis dari otak. Stimuli musik pada awal perkembangan akan sangat menentukan pengaruh dalam jangka waktu yang lama. Sebaliknya, awal pengalaman yang negatif (tanpa musik) akan mendapat konsekuensi dramatik yang berkepanjangan. Hubungan (interaksi) antara psikologi dan musik juga ditunjukkan oleh tumbuh kembangnya disiplin terapi musik dalam konteks pentingnya penga-laman musikal dalam kehidupan manusia (Zamil, 2016)

Ada beberapa musik yang dapat meningkatkan daya tangkap peserta didik yaitu musik klasik, musik barok dan ayat suci al quran. Selain yang telah disebutkan tersebut, salah satu jenis musik yang dapat membuat konsentrasi peserta didik dalam belajar adalah musik instrumental. Musik instrumen merupakan musik yang tidak disertai oleh alunan suara. Musik instrumen memiliki beberapa pengaruh dalam pembelajaran, selain bermanfaat sebagai media pembelajaran musik juga dapat membantu meningkatkan tingkat intelegensi peserta didik karena memiliki peranan dalam menyeimbangkan otak kiri dan otak kanan, sehingga dapat membantu peserta didik berkonsentrasi dalam proses pembelajaran. Selain membantu meningkatkan konsentrasi musik juga dapat membantu menciptakan suasana belajar yang rileks dan menyenangkan (Kotu, 2017).

Danny Salim staf pengajar fakultas seni pertunjukkan Universitas Kristen Satya Wacana Salatiga dalam penelitiannya yang berjudul Pengaruh Musik terhadap Konsentrasi belajar peserta didik kelas 2 SMUK 1 Salatiga. Dari penelitian yang Ia peroleh memperlihatkan bahwa belajar sambil mendengarkan musik favorit dapat meningkatkan konsentrasi belajar seorang siswa. Pengaruh ini bisa bersifat negatif atau positif. Pengaruh musik terhadap konsentrasi belajar disebabkan oleh paling sedikit tujuh faktor, yaitu : (1) emosi tertentu yang dibangkitkan oleh jenis musik tertentu, (2) Preferensi musik peserta didik, (3) Pengetahuan peserta didik sebelumnya mengenai topik yang dipelajari, (4) Teknik berpikir yang dibutuhkan, (5) Volume musik, (6) Karakter musik, dan (7) waktu pemutaran musik (Savitri, 2017)

Pendapat senada yang memperkuat pernyataan tersebut ialah Campbell (2001: 220221) yang mengungkapkan bahwa musik dapat menghilangkan stres sebelum ujian, membantu pembentukan pola pikir, mempengaruhi perkembangan emosi, spiritual, dan kebudayaan; sedangkan Ortiz (2002: 180) menambahkan bahwa musik juga dapat meningkatkan konsentrasi, menenangkan pikiran, meningkatkan kewaspadaan, dan mengurangi suara-suara eksternal yang bisa mengalihkan perhatian. Musikmusik populer (misalnya Baroque String Conceert) sangat efektif untuk membaca dan konsentrasi, sedangkan musik Klasik dan Baroque, apabila dirancang secara khusus dapat meningkatkan konsentrasi dan keinginan belajar.

Gardiner, berpendapat bahwa musik dapat membantu seseorang memfokuskan diri pada hal yang dipelajari, meningkatkan prestasi belajar membaca dan matematika anak usia enam dan tujuh, sependapat dengan pendapatt tersebut Jurnal The American Musik Teacher (Raharja, 2009) menyebutkan bahwa musik Mozart dapat mempengaruhi perkembangan intelektual dan kreativitas anak, yaitu (1) dapat meningkatkan kemampuan verbal, emosional, dan kecerdasan spasial, (2) memperbaiki konsentrasi dan memori, (3) menginspirasi otak kanan dalam proses kreatif, (4) memperkokoh kemampuan berpikir intuitif, (5) mendorong relaksasi, (6) memperbaiki gerakan tubuh dan koordinasi, dan (7) meningkatkan ketenangan atau suasana hati dan memelihara motivasi. 
Beberapa penelitian lain yang memperkuat pendapat di atas ialah penelitian yang dilakukan oleh Hidayat dengan judul penelitian Pengaruh Musik Klasik Terhadap Daya Tahan Konsentrasi Mahasiswa dalam Belajar, menunjukkan bahwa dari hasil pengamatan yang dilakukan terhadap kelompok ekperimen, terlihat bahwa subjek pada kelompok tersebut, menampilkan kondisi yang nyaman, santai dan rileks ketika membaca serta lebih tenang dari pada subjek pada kelompok kontrol. Hal ini dapat diketahui dari nilai rata-rata selisih antara pretest dan posttest kelompok eksperimen, yaitu 2,75 dibandingkan dengan nilai rata-rata dari selisih antara pretest dan posttest kelompok kontrol, yaitu 0,5. Musik klasik juga berpengaruh secara signifikan terhadap peningkatakn daya tahan konsentrasi, dengan nilait hitung 3,100 yang lebih besar dibandingkan dengan t-tabel 2,145. Berdasarkan hal ini maka dapat ditarik kesimpulan bahwa musik klasik mampu menciptakan susana yang rileks ketika subjek pada kelompok eksperimen melakukan kegiatan membaca. Kondisi yang rileks tersebut mempermudah subjek dalam berkonsentrasi, dengan daya tahan konsentrasi yang baik, akan meningkatkan kemampun subjek dalam belajar (Hidayat, 2011).

Data tersebut diperkuat dengan adanya penelitian yang dilakukan oleh Apriyani dengan judul penelitian pengaruh terapi musik murottal terhadap konsentrasi belajar siswa kelas V SD Muhammadiyah 2 Pontianak, mengungkapkan bahwa rata-rata skor konsentrasi belajar sebelum dilakukan terapi musik Murottal adalah 7,16 dan mengalami peningkatan menjadi 10,27 setelah dilakukan terapi musik Murottal. Berdasarkan analisa data yang dilakukan dapat disimpulkan bahwa ada pengaruh terapi musik Murottal terhadap konsentrasi belajar sebelum dan sesudah dilakukan intervensi yang dibuktikan dengan nilai $\mathrm{p}(0,000) \leq 0,05$.

Selanjutnya, berdasarkan hasil penelitian yang dilkukan oleh Roffiq, Qarim, \& Rubiono, (2017) pada anak sekolah dasar di studio musik Purwacaraka Surakarta menunjukkan bahwa bermain musik klasik dapat berpengaruh terhadap peningkatan prestasi belajar siswa. Bermain musik klasik dapat membuat siswa lebih cerdas dimana hasil penelitian menunjukkan kenaikan dari nilai uji $\mathrm{T}$ secara statistik dari nilai 83,87 menjadi 85,74 . Hal ini disebabkan karena musik klasik mengandung komposisi nada yang memberikan ketenangan, kenyamanan dan ketentraman dalam konsentrasi belajar.

\section{KESIMPULAN}

Berdasarkan kajian literatur yang telah penulis uraikan dalam pembahasan, dapat dinyatakan bahwa musik dapat digunakan dalam relaksasi untuk memperoleh konsentrasi dalam menerima pembelajaran. Belajar sambil mendengarkan musik favorit dapat meningkatkan konsentrasi belajar seorang siswa. Musik yang dapat memberikan ketenangan dan kedamaian adalah musik dengan tempo yang lebih lambat. Musik dengan tempo lambat tersebut dapat ditemukan dalam semua genre, salah satunya adalah musik instrumen. Adapun jenis musik yang dapat memengaruhi konsentrasi belajar dalam proses pemeblajaran diantaranya ialah musikmusik populer (misalnya Baroque String Conceert) sangat efektif untuk membaca dan konsentrasi, sedangkan musik Klasik dan Baroque, apabila dirancang secara khusus dapat meningkatkan konsentrasi dan keinginan belajar. Hal ini dapat memberikan gambaran adanya hubungan antara musik dengan respon seseorang yang sebenarnya tidak jauh dari hubungan emosi antar musik dan pendengar.

\section{DAFTAR PUSTAKA}

Apriyani, Y., Parjo, \& Rahmadhaniyati. (2015). Pengaruh Terapi Murottal Terhadap Konsentrasi Belajar Siswa Kelas V SD Muhammadiyah 2 Pontianak. Naskah Publikasi.

Hidayat, S. (2011). Pengaruh Musik Klasik Terhadap Daya Tahan Konsentrasi dalam Belajar. Skripsi Thesis, Universitas Islam Negeri Sultan Syarif Kasim Riau.

Izam, S. (2016). Pengaruh Musik Terhadap Kenyamanan Belajar Pengguna di Perpustakaan MIS LAMGUGOB Banda Aceh.

Kotu, J. T. (2017). Efektifitas Penggunaan Musik Terhadap Konsentrasi Belajar Fisika Kelas XI SMAN 3 Sungguminasa. Jurnal UIN Alauddin Makassar.

Raharja, B. (2009). Efek Musik Terhadap Prestasi Anak Usia Prasekolah. Jurnal Cakrawala Pendidikan, XXVIII(2), 132-144.

Roffiq, A., Qarim, I., \& Rubiono, G. (2017). Media Musik dan Lagu Pada Proses Pembelajaran. Jurnal Pendidikan Dasar Indonesia, 2(2), 35-40.

Savitri, A. E. (2017). Efektifitas Penggunaan Musik Instrumen Terhadap Peningkatan 
Konsentrasi dan Hasil Belajar Peserta Didik Pada Materi Gerak Harmonik dan Sifat Mekanik Bahan Kelas X TGB SMK N 1

Sulawesi Selatan. Jurnal Alauddin Makassar.

Supradewi, R. (2010). Otak, Musik , dan Proses Belajar. Buletin Psikologi, 18(2), 58-68.

Wulansari, M. S., Dewi, S., \& Murni, S. (2019).

Pengaruh MUSIK Instrumental Islami Terhadap Kemampuan Pemecahan Msalah Matematis siswa kelas III Pada pembelajaran Matematika Di Sekola Dasar. Journal of Elementary Education, 02(01), 10-17.

Zamil, I. (2016). Pengaruh Musik dan Lingkungan Belajar Terhadap Siswa. Juurnal PPKn \& Hukum, 11(2), 149-160. 